UDK: 811.111'367.635

Izvorni znanstveni članak

Primljen 3. IV. 2019.

Iva Grubišić ĆURIĆ

Sveučilište Josipa Jurja Strossmayera u Osijeku,

Fakultet agrobiotehničkih znanosti

igrubisic@fazos.hr

\title{
ODSTUPANJA PRI TVORBI REČENIČNE NEGACIJE U ENGLESKOME KAO INOME JEZIKU SREDNJOŠKOLSKIH UČENIKA
}

\section{Sažetak}

Iako je ovladavanje negacijom $\mathrm{u}$ inome jeziku temom brojnih istraživanja (Cancino i dr., 1975, Meisel, 1997, Fuentes, 2008), sustavne analize o tome kako govornici hrvatskoga jezika ovladavaju negacijom u engleskome jeziku izostaju. Stoga je cilj rada dobiti bolji uvid u vrstu i učestalost odstupanja pri relativno slobodnoj produkciji negacije u engleskome kao inome jeziku. Istraživanje se temeljilo na pretpostavkama da će najučestalija odstupanja biti kada je pri tvorbi rečenične negacije nužno dodavanje pomoćnoga glagola do (do staviti u kurziv), zatim izostavljanje pomoćnoga glagola kao i dvostruko označavanje. Istraživanje se temelji na upitniku sa zadatkom preoblike potvrdnih rečenica u niječne. Odgovori su zatim svrstani u skupine sukladno vrsti odstupanja. Pokazalo se da se najučestalija odstupanja mogu svrstati u kategoriju ostala odstupanja (37 \%), slijede dvostruko obilježavanje i sročnost (14\%), ispuštanje (12\%) te dodavanje (9\%). Rezultati potvrđuju pretpostavku o učestalosti odstupanja u rečenicama u kojima je bilo nužno dodati pomoćni glagol do pri tvorbi negacije, što je moguće tumačiti nepovoljnim prijenosom iz materinskoga hrvatskog jezika.

Ključne riječi: rečenična negacija; odstupanja; hrvatski jezik; engleski jezik 


\section{Uvod}

Niječnice su među prvim riječima koje djeca nauče, iako je negacija u jezicima daleko složenija pojava nego, primjerice, u logici ili matematici (usp. Dimroth, 2010,39; Nordmeyer - Frank, 2013, 3169). Ovladavanje ${ }^{1}$ negacijom temom je brojnih istraživanja, kako u materinskome tako i u inome jeziku (usp. Milon, 1974; Cazden i dr., 1975; Cancino i dr., 1975; Meisel, 1997; Fuentes; 2008, Dimroth; 2010)². Prvu je sustavnu analizu negacije $\mathrm{u}$ hrvatskome jeziku izradila Zovko Dinković $(2013)^{3}$, a Dankić i Karadža (2011) bavili su se utvrđivanjem uloge nepovoljnoga prijenosa iz hrvatskoga kao materinskoga na engleski kao ini jezik.

U hrvatskome jeziku za tvorbu niječnih glagolskih oblika rabi se niječna čestica ne ili $n i$ (usp. Silić - Pranjković, 2007), dok je u engleskome jeziku tvorba niječnih oblika složenija. Kod jednostavnih glagolskih oblika (izuzev pomoćnih i modalnih glagola) u niječnim je rečenicama nužno dopuniti predikat zanijekanim oblikom glagola do. Kada je riječ o mogućim poteškoćama s kojima se susreću govornici hrvatskoga pri ovladavanju negacije u engleskome, kontrastivnom analizom moguće je predvidjeti određene vrste odstupanja.

Cilj je ovoga rada, na tragu dosad postojećih istraživanja, doprinijeti istraživanju ovladavanja negacijom u engleskome jeziku kod izvornih govornika hrvatskoga jezika. U radu su prikazane poteškoće uočene kod učenika srednjoškolskoga uzrasta pri ovladavanju negacijom u engleskome jeziku. Istraživanje je provedeno na temelju upitnika sa zadatkom preoblike zadanih rečenica na engleskome jeziku u niječne (Eisouh, 2011).

Jelaska $(2007,86)$ navodi kako je pojam ovladavanje nadređen pojmu usvajanje jer podrazumijeva pojmove usvajanje i učenje, stoga će se u ovome radu rabiti pojam ovladavanje.

2 Pavičić Takač i Bagarić Medve (2013, 77 - 110) daju pregled istraživanja sintaktičke kompetencije učenika inoga jezika.

3 Uz navedenu monografiju, čijim je predmetom kontrastivna analiza negacije u engleskome i hrvatskome jeziku, valja dodati i Nazalević Čučević (2016a) koja daje kontrastivnu analizu sintaktičke negacije u hrvatskome i makedonskome jeziku te Kovačević (2016) koja opisuje negaciju u hrvatskome crkvenoslavenskom jeziku. 


\section{Teorijska pozadina}

Središnji su koncept ovoga istraživanja odstupanja koja Gulešić-Machata i Udier (2008: 19) definiraju kao „otklone od norme jezika koji se uči [i] obilježje svakog učeničkog međujezika”. Različite su klasifikacije odstupanja. Touchie (1986) navodi kako se odstupanja uglavnom dijele u dvije skupine: odstupanja u jezičnoj izvedbi i odstupanja uvjetovana kompetencijom. Razlikuju se zatim i prijenosna i razvojna odstupanja, pri čemu valja naglasiti da istraživanja upućuju na manji utjecaj materinskoga jezika nego što se smatralo. Primjerice Dulay i Burt (1974) tek su 4,7 \% odstupanja nedvojbeno svrstale u prijenosna. Julian Edge (1993) odstupanja dijeli u tri kategorije: lapsusi (engl. slips), odnosno odstupanja koja učenici mogu ispraviti samostalno, odstupanja (engl. errors), to jest odstupanja koja učenici ne mogu samostalno ispraviti jer iziskuju pojašnjenja, te pokušaji (engl. attempts) učenika da nešto izraze, no ne znaju kako to ispravno učiniti. Jelaska $(2005,100)$ navedenomu dodaje i pogreške (engl. mistakes), odnosno poteškoće u jezičnoj izvedbi uvjetovane umorom, bolešću i sličnim okolnostima.

Glavni su uzroci odstupanjima utjecaj materinskoga jezika i razvojne greške (usp. Touchie, 1986; Jelaska, 2005; Harmer, 2007). Učenje inoga jezika podrazumijeva poznavanje materinskoga jezika, tako se "govornici služe usvojenim pa na drugi jezik prenose obilježja materinskog, [što] se zove prijenosom" Jelaska $(2005,89)$. Razlikuju se povoljan prijenos koji olakšava ovladavanje i nepovoljan (interferencija) koji ga ometa (usp. Jelaska, 2005). Jelaska $(2005,95)$ naglašava da „osim utjecaja materinskog jezika i kognitivnoga razvoja pogreške mogu uzrokovati i vanjski utjecaji". Odstupanja se pojavljuju na svim jezičnim razinama (Harmer, 2007; Jelaska, 2005): fonetskoj, fonološkoj, morfološkoj, sintaktičkoj, semantičkoj, pragmatičkoj i kulturološkoj.

\subsection{Negacija}

Smatra se da je negacija univerzalna pojava u ljudskome jeziku (usp. Miestamo, 2007) te da je sposobnost poricanja, proturječenja, laganja ili izražavanja ironije svojstvena jedino ljudskomu jeziku (usp. Horn, 
2010, 1). Pojam negacije uglavnom je definiran kao „poricanje, proturječnost ili suprotnost nečemu potvrdnom" (usp. Zovko Dinković, 2013; Jespersen, 1917). Miestamo (2007, 552) navodi da je „negacija u propozicijskoj logici operator koji mijenja istinitost iskaza. Ako je $p$ istinit, not-p je neistinit i obratno “. Nadalje navodi kako je negacija u jeziku složen fenomen, a ne nužno puko dodavanje niječnoga markera potvrdnoj rečenici. Navedeno potkrepljuje istraživanjem koje je obuhvatilo otprilike 240 jezika (usp. Dahl, 1979) i u kojem je predložena tipologija s temeljnom razlikom između morfološke (prefiksalna, sufiksalna, cirkumfiksalna, prozodijska i reduplikativna) i sintaktičke negacije (čestica, pomoćni glagol). Kroeger (2005) također navodi da se negacija različito izražava u svjetskim jezicima, što oprimjeruje niječnim riječima u malajskome, afiksima u hebrejskome i turskome, niječnim pomoćnim glagolom u finskome itd., a svim je primjerima zajedničko to što se potvrdnoj rečenici nešto mora dodati kako bi se preoblikovala u niječnu.

\subsubsection{Negacija u hrvatskome jeziku}

Katičić $(2002,140)$ negaciju definira kao „preobliku koja zahvaća čitavo rečenično ustrojstvo [i kojom] se otklanja i poriče rečenični izričaj (rijek) kako je sadržan u tom ustrojstvu". Nadalje navodi kako se negacija izriče dodavanjem niječne čestice ne neposredno pred glagolski oblik u predikatu. Zovko Dinković $(2013,146)$ tvrdi da se negacija ostvaruje na različitim jezičnim razinama: na leksičkoj (sretan - nesretan), sastavničkoj (Teško je ne dijeliti njezino mišljenje.), rečeničnoj razini (Iris nije zaspala.) i na razini teksta (A: Je li zaspala? B: Nije.).

Za razliku od engleskoga jezika, u hrvatskome je moguće rabiti dvostruku negaciju. Pravilo logike i matematike da se dva minusa (u ovome slučaju negacije) međusobno nište i daju plus (ovdje potvrdno) do određene mjere vrijedi u engleskome standardnom jeziku (not unexpected - „nije neočekivano“). Slijedom navedenoga, rečenica koja sadrži dvostruku negaciju (1) u standardnome je engleskom jeziku neprihvatljiva, a rečenica koja sadrži jednu negaciju (2) prihvatljiva. U hrvatskome 
standardnom jeziku potpuno je prihvatljiva rečenica (3) koja sadrži dvostruku negaciju. ${ }^{4}$

(1) *Nobody did not come.

(2) Nobody came.

(3) Nitko nije došao.

Za razliku od engleskoga jezika, u hrvatskome je moguć veći broj niječnih markera, što je razvidno iz primjera (4):

(4) Nikada nitko nije ništa nikomu netočno rekao. (Ćoso, 2015: 25)

U standardnome engleskom jeziku višestruka negacija nije uobičajena, ali se rabi u nestandardnim dijalektima.

(5) I didn't never mean no harm to nobody or nothin'. (Pullum, 2012)

„Nikada nisam htio naštetiti nikomu ni ničemu."

(6) I didn't ever mean any harm to anybody or anything.

Primjere (5) i (6) Pullum (2012) navodi kao fenomen niječnoga slaganja (engl. negative concord) i razlikuje ga od dvostruke negacije. Rečenica (5) primjer je nestandardnoga višestrukog nijekanja, a rečenica (6) primjer rečenične negacije u standardnome engleskom jeziku.

\subsubsection{Negacija u engleskom jeziku}

Klima (1964) razlikuje rečeničnu (engl. sententential negation) i sastavničku negaciju (engl. constituent negation) te predlaže sintaktičke testove za polaritet rečenice $u$ engleskome jeziku. ${ }^{5} \mathrm{U}$ sljedećim je primjerima jedna rečenica niječna (8), a druga nije (7).

(7) They live not far from here. „Žive nedaleko odavde.“

(8) They don't live far from here. „Ne žive daleko odavde."

4 Zovko Dinković $(2013,230)$ smatra da se, budući da hrvatski jezik dopušta niječno slaganje, „pravom dvostukom negacijom trebaju smatrati samo oni primjeri u kojima dvije ili više niječnih riječi u rečenici rezultiraju potvrdnošću".

5 Nazalević Čučević (2016b, 331) navodi da je termin rečenična negacija najzastupljeniji u kroatističkoj literaturi za nijekanje (su)rečeničnoga sadržaja u cjelini, a za nijekanje nepredikatnoga člana rečeničnoga ustrojstva sastavnič̌ka, odnosno parcijalna negacija. 
Iako rečenica (7) sadrži niječni element not, nije niječna jer not niječe konstituent far from here. Klima (1964) predlaže testove za niječne rečenice. Prvi je test dopunskih pitanja (engl. question tags). Dopunska pitanja služe traženju slaganja ili potvrđivanja izrečenoga u glavnoj rečenici (Thomson - Martinet, 1995, 113). U slučaju da govonik ne traži informacije, već samo slaganje s izrečenim, intonacija dopunskih pitanja uglavnom je padajuća. Intonacija je rastuća ako govornik nije siguran u točnost izrečenoga i traži potvrdu. Kada se rečenica (9) podvrgne testu dopunskih pitanja, rezultat je sljedeći:

(9) a. Ed didn't read it, did he? „Ed to nije pročitao, zar ne?“

b. Ed read it, didn't he? "Ed je to pročitao, zar ne?"

Idući je test dodavanje apozicijske dopune (not) even, što nije moguće u potvrdnim rečenicama ( $1 \mathrm{ob})$ :

(10) a. He didn't read it, not even the abstract. „Nije to pročitao, čak niti sažetak."

b. "He read it, not even the abstract. " „Pročitao je, čak niti sažetak."

Treći je test dodavanje neither ili nor dopune. Niječnu rečenicu moguće je dopuniti s neither (11a), ali ne sa so (11b), dok je potvrdnu rečenicu moguće nadopuniti sa so (11c), ali ne i s neither.

(11) a. He didn't read it, neither did I. „On to nije pročitao, a nisam ni ja."

b. "He didn't read it, so did I. " „On to nije pročitao, a i ja sam."

c. He read it, so did I. "On je to pročitao, a i ja sam."

Huddleston i Pullum $(2002,786)$ ističu kako negacija može biti označena riječima (not, no, never, itd.) ili afiksima (-n't, un-). Također može biti izražena i neizravno, pomoću neizravne (engl. implicit) niječne riječi.

(12) a. On je sretan. (Ćoso, 2015)

b. On nije sretan.

c. On je nesretan.

d. On je tužan. 
Rečenica (12b) nijekanjem je preoblikovana iz (12a), dok su rečenice (12c) i (12d) semantički niječne. Ćoso $(2015,26)$ pojašnjava kako je $u$ slučaju eksplicitno zanijekane rečenice niječnost nedvojbena, dok kod implicitne ovisi o interpretaciji subjekta. Pullum (2012) razlikuje različite tipove negacije: glagolsku i neglagolsku, analitičku i sintetičku, rečeničnu i sastavničku, standardnu i metalingvističku.

Rečenica (13a) primjer je glagolske negacije jer je niječni morfem sufiks $-n$ 't. U rečenici (13b) niječni morfem nije glagol, stoga nije riječ o glagolskoj negaciji.

(13) a. I couldn't ever lie to her. „Nikad joj ne bih mogao lagati.“ (Pullum, 2012)

b. I could never lie to her.

Primjer je analitičke negacije rečenica (14a) jer je niječni morfem riječ not. U primjeru (14b) niječni je morfem suffix $-n$ 't, stoga je riječ o sintetičkoj negaciji.

(14) a. This is not complete. „Ovo nije čitavo.“ (Pullum, 2012)

b. This isn't complete.

Rečenična se negacija razlikuje u primjeru (15a) od sastavničke (15b). U primjeru (15a) negirana je čitava rečenica, u (15b) jedino pridjevska fraza.

(15) a. She didn't have any substantial income. (Pullum, 2012)

b. She had a not insubstantial income. „Imala je prihode koji nisu bili neznatni."

U primjeru (16a) riječ je o standardnoj negaciji jer tvrdnja „on ima četvero djece" nije točna. U primjeru (16b) riječ je o metalingvističkoj negaciji jer je tvrdnja da „on ima četvero djece” zapravo točna - tko ima petero djece, ima četvero.

(16) a. He hasn't got four kids; he's got three. „Nema četvero djece, ima troje." (Pullum, 2012)

b. He hasn't got four kids; he's got five. „Nema četvero djece, ima petero." 


\subsection{Pomoćni glagol "do"}

Budući da je jedna od pretpostavki istraživanja učestalost grešaka u ispuštanju, odnosno dodavanju pomoćnoga glagola do, nužan je kratak osvrt na navedenu pojavu u engleskome jeziku. U određenim konstrukcijama u engleskome jeziku, a Huddleston $(2006,45)$ ih navodi četiri, nužno je rabiti pomoćni glagol do kako bi rečenica bila ovjerena. U navedenim je slučajevima glagol do pomoćno sredstvo odnosno potpora (engl. do support, dummy do) jer je semantički prazan i ispunjava čisto sintaktički zahtjev (usp. Huddleston, 2006, 45). Ako predikat ne sadržava pomoćni glagol, niječni se oblik tvori dodavanjem pomoćnog glagola do:

(17) a. It is raining. 'Kiši'.

b. It isn't raining. 'Ne kiši'.

U primjeru (17) glagol is je pomoćni pa se dodaje negacija not, dok je u primjeru (18) nužno dodati pomoćni glagol $d o$.

(18) a. She rejected his offer. „Odbila je njegovu ponudu."

b. She didn't reject his offer. "Nije odbila njegovu ponudu.“

U imperativnim rečenicama s glagolskom negacijom uvijek se dodaje do:

(19) a. Reject his offer. „Odbij njegovu ponudu““

b. Don't reject his offer. „Nemoj odbiti njegovu ponudu."

\section{Metodologija}

Cilj je ovoga istraživanja ispitati u kolikoj su mjeri učenici ovladali negacijom u engleskome jeziku i koliki je utjecaj njihova materinskog jezika na učenje inoga jezika. Moguće je pretpostaviti da će najzastupljenija odstupanja biti u rečenicama u kojima je nužno dodati pomoćni glagol do jer u hrvatskome jeziku ne postoji takva konstrukcija. Odstupanja vezana za dvostruka obilježavanja ("Karin didn't played football.) također su moguća zbog poopćavanja pravila tvorbe upitnih i niječnih oblika preteritana određenim razinama učenja inoga jezika. Mogući su 
i primjeri izostavljanja pomoćnoga glagola, odnosno konstrukcije uvjetovane nepovoljnim prijenosom iz hrvatskoga jezika ("Sue not have a black car.).

U istraživanju je sudjelovao trideset i jedan učenik srednje škole. Svi su učenici na B1 razini (samostalni korisnik) prema Zajedničkomu europskom referentnom okviru za jezike (ZEROJ). Ispitanicima je uručen upitnik koji se sastojao od jednoga zadatka preoblike potvrdnih rečenica na engleskome jeziku u niječne. Test se sastojao od četrnaest rečenica koje su preuzete s interneta ${ }^{6}$ i nadopunjene vlastitim primjerima. ${ }^{7}$ Dvije su rečenice sadržavale glagole have i have got, jedna je rečenica sadržavala kopulu be. Četiri je zadane rečenice bilo nužno nadopuniti pomoćnim glagolom do (engl. do support). Ovakav zadatak doimao se primjerenim za ispitivanje relativno samostalne proizvodnje negacije glagola $u$ engleskome jeziku. Eisouh (2011) je, osim zadatka preoblike potvrdnih rečenica u niječne, $u$ istraživanje uvrstio i zadatak višestrukoga izbora te zadatak dopunjavanja, a Dankić i Karadža (2011) istraživanje su temeljile na zadatku utvrđivanja preferencije prihvatljivosti, zadatku prosudbe prihvatljivosti i zadatku prevođenja rečenica s hrvatskoga na engleski jezik. Upitnik korišten u ovome istraživanju nije sadržavao zadatke višestrukoga odabira kako ne bi utjecali na rezultate. Svrha ovakva zadatka bila je prikupiti podatke o ovladanosti pravilima tvorbe rečenične negacije u engleskome jeziku. Kod složenih glagolskih oblika valjalo je umetnuti negaciju not na mjesto iza pomoćnoga, a ispred glavnoga glagola (are watching $\rightarrow$ are not watching), dok je kod jednostavnih glagolskih oblika bilo nužno nadopuniti zadane rečenice pomoćnim glagolom i negacijom not (speaks $\rightarrow$ does not speak).

Odgovori učenika zatim su svrstani u šest kategorija sukladno vrsti odstupanja: dvostruko označavanje ("didn't played), odstupanja u sročnosti subjekta i predikata ("Sue don't have), dodavanje ("we are don't writing), ispuštanje ("Mel not speak), pravopisna ("hadent see) i ostala odstupanja.

$6 \quad$ Izvor: https://www.englisch-hilfen.de/en/exercises/tenses/negation.htm (10. I. 2016.). Deset je rečenica preuzeto $s$ interneta te su im pridružena četiri vlastita primjera.

Cjelovit upitnik sadržan je u Dodatku A. 
U svrhu istraživanja uobličene su sljedeće hipoteze: najučestalija će biti odstupanja u slučajevima kada je pri tvorbi rečenične negacije nužno dodati pomoćni glagol do te odstupanja izostavljanja pomoćnoga glagola kao moguće posljedice nepovoljna prijenosa iz materinskoga hrvatskog jezika. Također se predviđaju odstupanja dvostrukoga označavanja koja bi se mogla pripisati poopćavanju pravila tvorbe preterita u engleskome jeziku.

\section{Rezultati}

U svrhu analize odstupanja su podijeljena u šest kategorija: dvostruko označavanje, dodavanje, ispuštanje, sročnost, pravopisna odstupanja i ostala. U Tablici 1. prikazani su broj i postotak točnih i netočnih rješenja preoblike potvrdnih rečenica u niječne.

Tablica 1. Omjer odstupanja i točnih rješenja

\begin{tabular}{|l|l|l|l|l|}
\hline & \multicolumn{2}{|l|}{$\begin{array}{l}\text { Broj točnih } \\
\text { rješenja }\end{array}$} & \multicolumn{2}{l|}{$\begin{array}{l}\text { Broj netočnih } \\
\text { rješenja }\end{array}$} \\
\hline Sue has a black car. & 7 & $22,58 \%$ & 24 & $77,41 \%$ \\
\hline $\begin{array}{l}\text { Karin played volleyball } \\
\text { yesterday. }\end{array}$ & 8 & $25,8 \%$ & 23 & $74,19 \%$ \\
\hline $\begin{array}{l}\text { There will be rain in the } \\
\text { South tomorrow. }\end{array}$ & 15 & $48,38 \%$ & 16 & $51,61 \%$ \\
\hline Mel speaks German. & 9 & $29,03 \%$ & 22 & $70,96 \%$ \\
\hline We are writing a test. & 24 & $77,41 \%$ & 7 & $22,58 \%$ \\
\hline Listen to Thomas. & 24 & $77,41 \%$ & 7 & $22,58 \%$ \\
\hline $\begin{array}{l}\text { They are going to rent a } \\
\text { car. }\end{array}$ & 23 & $74,19 \%$ & 8 & $25,8 \%$ \\
\hline I had seen him. & 17 & $54,83 \%$ & 14 & $45,16 \%$ \\
\hline $\begin{array}{l}\text { They were having a cup of } \\
\text { tea this morning. }\end{array}$ & 22 & $70,96 \%$ & 9 & $29,03 \%$ \\
\hline She has been to Berlin. & 25 & $80,64 \%$ & 6 & $19,35 \%$ \\
\hline $\begin{array}{l}\text { I have been watching TV } \\
\text { for an hour. }\end{array}$ & 21 & $67,74 \%$ & 10 & $32,25 \%$ \\
\hline I am a student. & 26 & $83,87 \%$ & 5 & $16,12 \%$ \\
\hline
\end{tabular}




\begin{tabular}{|l|l|l|l|l|}
\hline $\begin{array}{l}\text { It was an unforgettable } \\
\text { experience. }\end{array}$ & 23 & $74,19 \%$ & 8 & $25,80 \%$ \\
\hline I have got a bag. & 20 & $64,51 \%$ & 11 & $35,48 \%$ \\
\hline
\end{tabular}

U sljedećim je primjerima slovom a. označena ona rečenica koja je bila zadana u testu, dok su rečenice označene slovima b. i c. točna rješenja. Ostalim su slovima označena rješenja učenika koja su predmet analize. Zvjezdicom (*) su označena odstupanja. Pojedine rečenice iz upitnika nisu dio ove analize, posebice u slučajevima u kojima su najbrojnije greške klasificirane kao „ostala” ili „pravopisna odstupanja”.

(20) a. Sue has a black car. „Sue ima crni automobil.“

b. Sue doesn't have a black car.

c. Sue does not have a black car.

d. "Sue hasn't a black car.

e. "Sue don't have a black car.

f. "Sue not have a black car.

U niječnim inačicama rečenice (20a) najčešće je odstupanje izostavljanje pomoćnoga glagola do (Sue hasn't a black car.). Navedeno je odstupanje uočeno kod 15 ispitanika (48,38\%). U ovome se istraživanju navedeno rješenje smatra netočnim, iako se u literaturi spominje da pomoćni i modalni glagoli (be, have, do, can, will, itd.) imaju niječni oblik u paradigmi. Tako glagol have ima i oblik haven't, hasn't i hadn't. Navedeni se niječni oblici glagola have rabe u složenim glagolskim oblicima kao pomoćni glagoli ili primjerice, u dopunskim pitanjima (engl. question tags). Budući da je u ovome radu u obzir uzet jedino engleski standardni jezik, kao točna mogu se jedino u obzir uzeti rješenja Sue does not have a black car ili Sue doesn't have a black car.

$\mathrm{U}$ rezultatima je pronađena i jedna pojavnica not have. $\mathrm{U}$ tome je primjeru riječ o ispuštanju pomoćnoga glagola do i odabiru pogrešna oblika glagola have jer se u trećem licu jednine koristi oblik has. Dva je puta uočen pogrešan oblik glagola have u kombinaciji s ispravnim niječnim elementom (doesn't had). Riječ je o prošlome obliku glagola have.

Osim izostavljanja glagola $d o$, pronađena su i tri primjera pravopisnih pogrešaka (Sue dasnt have / dosent have / has't a black car.), odnosno 
ispuštanja apostrofa $\mathrm{u}-n^{\prime}$ ' $\mathrm{i}$ pogrešno napisana glagola do, tj. does. Te se greške u ovome kontekstu mogu smatrati propustom i nisu relevantne za ovu analizu zbog maloga broja pojavnica te nemogućnosti provjere njihove sustavnosti.

(21) a. Karin played volleyball yesterday. „Karin je jučer igrala odbojku."

b. Karin didn't play volleyball yesterday.

c. Karin did not play volleyball yesterday.

d. "Karin didn't played volleyball yesterday.

e. "Karin doesn't played volleyball yesterday.

f. Karin hasn't played volleyball yesterday.

g. "Karin wasn't played volleyball yesterday.

h. "Karin don't played volleyball yesterday.

i. "Karin is not play volleyball yesterday.

j. "Karin not played volleyball yesterday.

U slučaju (21) najučestalija su odstupanja dvostrukoga označavanja (didn't played), što je moguće objasniti razvojnim greškama (Harmer, 2007). Odstupanja poopćavanja naučenih pravila mogu uzrokovati uporabu prošloga oblika pravilnih i nepravilnih glagola u upitnim i niječnim rečenicama, iako je glagolsko vrijeme u takvim rečenicama izraženo pomoćnim glagolom $d o$.

Također su uočena odstupanja dvostrukoga obilježavanja, ali s pomoćnim glagolom u pogrešnome glagolskom vremenu (doesn't, hasn't, wasn't), što se može tumačiti nedovoljnim poznavanjem pravila tvorbe glagolskih oblika. Valja napomenuti kako glagolski oblik wasn't played nije u aktivu, već je u pasivu, što rečenicu (21g) čini ovjerenom, ali nelogičnom, jer bi na mjestu subjekta trebao biti npr. instrument, nipošto osoba. Zanimljivo je što je jedan ispitanik upotrijebio konstrukciju is not play, a uočeno je i jedno odstupanje izostavljanja pomoćnoga glagola (not played), što se može tumačiti kao nepovoljan prijenos iz materinskoga jezika. 
(22) a. There will be rain in the South tomorrow. „Sutra ce na jugu biti kiše."

b. There will not be rain in the South tomorrow.

c. There won't be rain in the South tomorrow.

d. "There not will be rain in the South tomorrow.

e. "There don't be rain in the South tomorrow.

f. "There won't rain in the South tomorrow.

g. *There doesn't will be rain in the South tomorrow.

h. *There willn't be rain in the South tomorrow.

U slučaju (22) odstupanja su raznovrsna: red riječi (not will be), zamjena glagola will s do (don't be), ispuštanja glagola be (won't) i jedan primjer netočna negiranja glagola will (willn't). Odstupanje u primjeru (22f) može se pripisati poteškoćama pri ovladavanju ekspletivnim subjektima $\mathrm{u}$ engleskome jeziku there ili $i t$, a konstrukcija bez glagola be bila bi točna u slučaju subjekta it.

(23) a. Mel speaks German. „Mel govori njemački.“

b. Mel does not speak German.

c. Mel doesn't speak German.

d. "Mel doesn't speaks German.

e. "Mel don't speaks German.

f. "Mel don't speak German.

g. "Mel no speaks German.

h. "Mel not speak German.

U slučaju (23) najčešća su odstupanja bila dvostruko označavanje (doesn't speaks) te dvostruko označavanje s netočnim oblikom glagola do (don't speaks, didn't speaks). Uočena su i odstupanja ispuštanja pomoćnoga glagola do (not speak, no speaks) kao i ortografske greške (dose not speak, doesn't speaks).

(24) a. We are writing a test. „Pišemo ispit."

b. We are not writing a test.

c. We aren't writing a test. 
d. "We are don't written a test.

e. "We are don't writing a test.

f. "We don't writing a test.

Rečenica iz primjera (24) točno je preoblikovana u niječnu u 77,41 \% slučajeva. Uočena su odstupanja umetanja glagola do i ispuštanja glagola be (don't written, don't writing) te umetanja niječnoga oblika glagola do umjesto negacije not između pomoćnoga i glavnoga glagola (are don't writing).

(25) a. Listen to Thomas. „Slušaj Thomasa.“

b. Do not listen to Thomas.

c. Don't listen to Thomas.

d. "Doesn't listen to Thomas.

e. "Don't listen Thomas.

f. "Didn't listen to Thomas.

U slučaju (25) riječ je o imperativu. Odstupanje u primjeru (25d) sadrži glagol $u$ indikativu, ali nedostaje subjekt u trećem licu jednine. Iako je glagol u primjeru (25e) u imperativu, zbog ispuštanja prijedloga to zapovijed se odnosi na Thomasa.

(26) a. They are going to rent a car. „Unajmit će automobil.“

b. They are not going to rent a car.

c. They aren't going to rent a car.

d. "They are don't go to rent a car.

e. *They not rent a car.

f. "They don't going to rent a car.

U primjeru (26) uočena su odstupanja umetanja niječnoga oblika glagola do i ispuštanja nastavka -ing (are don't go to rent), ispuštanja glagola be i konstrukcije going to (not rent) te zamjenom glagola be i niječnim oblikom glagola $d o$. Navedena odstupanja mogu se protumačiti nedovoljnim poznavanjem pravila tvorbe ili neprepoznavanjem tzv. going to futura.

(27) a. I had seen him. „Vidio sam ga." 
b. I had not seen him.

c. I hadn't seen him.

d. "I don't had seen him.

e. "I haven't seen him.

f. "I didn't seen him.

g. "I didn't saw him.

U slučaju (27) uočena su brojna pravopisna odstupanja (haden't see, had't see, haden't seen). Često odstupanje bilo je mijenjanje prošloga oblika glagola have (had) sadašnjim (have), što se može protumačiti propustom, ne nužno sustavnim odstupanjem. Učestalo su rješenja sadržavala dodavanje glagola do (don't had seen, didn't seen, didn't saw, don't see).

(28) a. She has been to Berlin. „Bila je u Berlinu““

b. She has not been to Berlin.

c. She hasn't been to Berlin.

d. "She don't has been to Berlin.

e. "She isn't been to Berlin.

f. "She haven't been to Berlin.

g. "She doesn't be to Berlin.

U slučaju (28) rješenja su sadržavala netočno mijenjanje pomoćnoga glagola have s is ili do uz netočnu uporabu infinitiva glavnoga glagola (isn't been, doesn't be) te dodavanje glagola do (don't has been). Također je uočeno i pogrešno označavanje lica (haven't been).

(29) a. I am a student. „Ja sam učenik/student.“

b. I am not a student.

c. I'm not a student.

d. "I'am not a student.

e. "I am no student.

f. "I not a student.

g. "I am didn't a student. 
Osim ispuštanja glagola be (I [] not a student) i dodavanja glagola do (am didn't), u ovome je primjeru uočena zanimljivost - jedan je ispitanik umjesto rečenične negacije uporabio sastavničku (no student). Navedena je rečenica ovjerena, ali stilski obilježena.

(30) a. I have got a bag. „Imam torbu.“

b. I've not got a bag.

c. I haven't got a bag.

d. "I not a bag.

e. "I don't have a bag.

f. "I have not a bag.

Dva su načina u engleskome jeziku kada glagol have u svojstvu glavnoga glagola izriče posvojnost: have i have got. Potonji oblik karakterističan je primarno za britanski engleski. Oba su primjera zadana u testu jer se obrađuju tijekom nastave engleskoga jezika. I u ovome je slučaju pronađeno odstupanje ispuštanja, i to cjelokupnoga predikata (I [] not a bag) te got (have not). U nekoliko je slučajeva konstrukcija have got negirana kao have (don't have). 


\section{Diskusija}

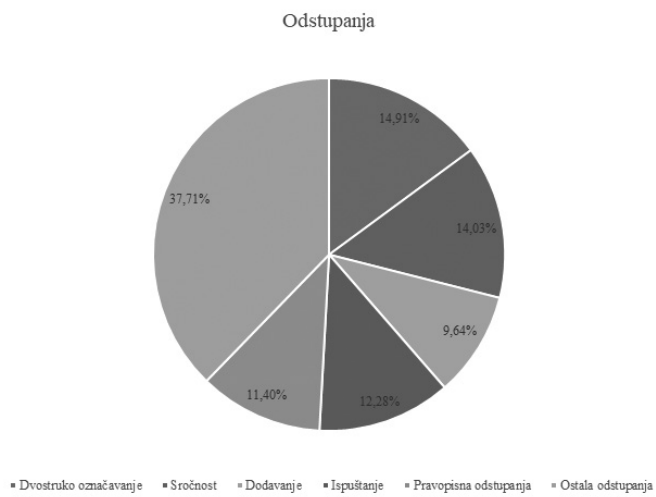

Slika 1.: Prikaz distribucije odstupanja po kategorijama.

Kao što je prikazano u Tablici 1, analiza rezultata upitnika pokazala je da su odstupanja svrstana u kategoriju ostala najučestalija (37,71\%). Navedena skupina odstupanja sadrži odstupanja koja imaju obilježja dviju kategorija. Tako su odstupanja u sročnosti pomoćnoga glagola i subjekta, u slučaju da je i glavni glagol netočan, svrstana u ovu kategoriju. Ako je predikat rečenice $u$ različitome glagolskom vremenu od zadane rečenice, ta su odstupanja također svrstana u ovu kategoriju. Dvostruka označavanja s pogrešnim pomoćnim glagolom, odnosno pomoćnim glagolom u netočnome glagolskom vremenu, klasificirana su kao ostala odstupanja.

U nekoliko slučajeva zabilježeno je nepotrebno dodavanje glagola $d o$, odnosno mijenjanje pomoćnoga glagola (be, have) glagolom do. Moguće je da je navedeno uzrokovano poopćavanjem pravila dodavanja pomoćnoga glagola do u jednostavnim glagolskim oblicima u potvrdnoj rečenici (izuzev kod glagola be, can, have, will, itd.). Također je moguće da je uzrok nedovoljno poznavanje pravila tvorbe složenih glagolskih oblika u engleskome jeziku.

Dvostruko označavanje i odstupanja u oznakama kategorije lica pojavljuju se u uzorku približno jednako $(\approx 14 \%)$. Dvostruko je označavanje (didn't played, doesn't plays) moguće tumačiti poopćavanjem naučenih pravila, odnosno primjenom pravila tvorbe jednostavnih oblika 
u potvrdnim rečenicama na njihove niječne preoblike. Ako se utjecaj materinskoga jezika uzme u obzir kao važan faktor u ovladavanju inim jezikom, pogreške u označavanju lica začuđujuće su. Budući da hrvatski jezik ima, primjerice, prezentske nastavke (id-e-m, id-e-š, id-e- $\varnothing$, id-emo, id-e-te, id- $\varnothing-u$ ), a engleski prezentski nastavak ima jedino u trećem licu jednine u potvrdnim rečenicama (play-s, go-es), izvorni govornik hrvatskoga jezika na određenim razinama učenja engleskoga jezika ne bi trebao imati poteškoća s navedenim. Slijedom navedenoga moguće je da su takva odstupanja razvojne greške.

U uzorku su uočene greške dodavanja $(\approx 10 \%)$ i ispuštanja ( $\approx 12 \%)$, greške dodavanja moguće je pojasniti poopćavanjem naučenih pravila, a potonje utjecajem materinskoga jezika jer je konstrukcija not work slična konstrukciji ne radim.

Pravopisna odstupanja $(11,4 \%)$ u ovoj analizi nisu uzeta u obzir jer nije bilo moguće provjeriti njihovu sustavnost te su okarakterizirana kao propusti.

\section{Zaključak}

Prema rezultatima analize može se zaključiti da je prva pretpostavka, dakle učestalost odstupanja u rečenicama u kojima je nužno dodati pomoćni glagol do (engl. dummy support), potvrđena. Postotak točnih rješenja tih rečenica bio je manji od 30 \%. Navedena odstupanja moguće je tumačiti nepovoljnim prijenosom iz materinskoga jezika. Valja napomenuti da su ispitanici u pojedinim slučajevima dodavali pomoćni glagol do unatoč činjenici da je predikat zadane potvrdne rečenice sadržavao pomoćni glagol, na što možda utječe poopćavanje naučenih pravila.

Druga pretpostavka o dvostrukim obilježavanjima također se potvrdila. Otprilike 14 \% evidentiranih odstupanja otpada upravo na dvostruka obilježavanja. Treća pretpostavka o ispuštanju pomoćnoga glagola također je djelomično potvrđena rezultatima ( $\approx 12 \%)$. Ta je odstupanja moguće povezati s poopćavanjem naučenih pravila.

Broj ispitanika koji su sudjelovali u ovome istraživanju premalen je da bi bio reprezentativan, ali se rezultati u određenoj mjeri svejedno 
mogu smatrati indikativnima. U daljnjim istraživanjima bilo bi potrebno uključiti veći broj ispitanika na različitim razinama učenja jezika i nadopuniti test različitim tipovima zadataka.

\section{Literatura}

- Cancino, Herlinda - Rosansky, Ellen J. - Schumann, John H. (1975) „The Acquisition of the English Auxiliary by Native Spanish Speakers“, TESOL Quarterly, Wiley-Blackwell, god. Ix, br. 4, str. $421-430$.

- Cazden, Courtney B. i dr. (1975) Second language acquisition sequences in children, adolescents and adults. Final report, U. S. Department of Health, Education and Welfare, Washington.

- Ćoso, Bojana (2015) Kognitivna obrada različitih hrvatskih niječnih rečenica $i$ njihov prijenos u engleski jezik, doktorska disertacija, Centar za poslijediplomske studije, Zagreb.

- DAhL, Östen (1979) „Typology of sentence negation“, Linguistics, De Gruyter, god. XVII, br. 1 - 2, str. 79 - 106.

- Dankić, Izabela - KaradžA, Matea (2011) „Interference between Croatian and English: A pilot study on the acquisition of English negation", Hum, Mostar, br. 7, str. $68-78$.

- Dimroth, Christine (2010) „The acquisition of negation“, The expression of negation, Horn, LAURENCE R. (ur.), De Gruyter Mouton, Berlin - New York, str. $39-73$.

- Dulay, Heidi C. - Burt, Marina K. (1974) „Errors and Strategies in Child Second Language Acquisition“, TESOL Quarterly, Wiley-Blackwell, god. viII, br. 2, str. $129-136$.

- Edge, Julian (1993) Mistakes and Correction, 4. izd., Longman, London - New York.

- Eisouh, Zuhair S. (2011) „Negation errors in English by University of Jordan students", Reading Improvement, god. XLVIII, br. 3, str. $139-154$. 
- Fuentes, Araceli García (2008) „The Use of English Negation by Spanish Students of English: A Learner Corpus-Based Study“, Proceedings 31st AEDEAN Conference, Lorenzo Modia, M. J. (ur.), Universidade, A Coruña, str. $315-327$.

- Gulešić-Machata, Milvia - Udier, Sanda lucija (2008) „Izvorna odstupanja u hrvatskome kao inojezičnome“, LAHOR: časopis za hrvatski kao materinski, drugi i strani jezik, Zagreb, br. 5, str. $19-33$.

- Harmer, Jeremy (2007)The Practice of English Language Teaching, Pearson Education Limited, Harlow.

- Horn, Laurence R. (2010) „Introduction“, The expression of negation, Horn, Laurence R. (ur.), De Gruyter Mouton, Berlin New York, str. $1-9$.

- Huddleston, Rodney (2006) English grammar. An outline,Cambridge University Press, Cambridge.

- Huddleston, Rodney - Pullum, Geoffrey K. (2002) The Cambridge Grammar of the English Language, Cambridge University Press, Cambridge.

- Jelaska, Zrinka I DR. (2005) Hrvatski kao drugi i strani jezik, Hrvatska sveučilišna naklada, Zagreb.

- Jelaska, Zrinka (2007) „Ovladavanje jezikom: izvornojezična i inojezična istraživanja", LAHOR: časopis za hrvatski kao materinski, drugi i strani jezik, Zagreb, br. 3, str. 86 - 99.

- Jespersen, Отto (1917) Negation in English and other languages, Bianco Lunos Bogtrykkeri, Kopenhagen.

- Katičić, Radoslav (2002) Sintaksa hrvatskoga književnog jezi$k a$, HAZU - Nakladni zavod Globus, Zagreb.

- Klima, Edward (1964) „Negation in English“, The Structure of Language: Readings in the Philosophy of Language, Fodor, J. A. - Katz, J. J. (ur.), Prentice-Hall, Englewood Cliffs, str. 246 - 323. 
- Kovačević, Ana (2016) Negacija od čestice do teksta. Usporedna $i$ povijesna raščlamba negacije u hrvatskoglagoljskoj pismenosti, Staroslavenski institut, Zagreb.

- Kroeger, Paul R. (2015) Analyzing Grammar: An Introduction, Cambrige University Press, Cambridge.

- MeISel, JÜrgen M. (1997) „The acquisition of the syntax of negation in French and German: contrasting first and second language development", Second Language Research, Sage, god. XIII, br. 3, str. $227-263$.

- Miestamo, Matti (2007) „Negation - An Overview of Typological Research", Language and Linguistics Compass, Wiley, god. I, br. 5 , str. $552-570$.

- Milon, John P. (1974) „The Development of Negation in English by a Second Language Learner", TESOL Quarterly, Wiley-Blackwell, god. VIII, br. 2, str. $137-143$.

- NazAlević ČučEvić, Iva (2016a) Sintaktička negacija. Usporedna analiza sintaktičke negacije u hrvatskome i makedonskome je$z i k u$, Hrvatska sveučilišna naklada, Zagreb.

- Nazalević Čučević, Iva (2016b) „Negacija u vremenskim rečenicama s veznikom dok u hrvatskome jeziku", Romanoslavica, Slavic Association of Romania, god. LII, br. 2, str. 331 - 341.

- Normeyer, AnN - Frank, Michael (2013) „Measuring the comprehension of negation in 2- to 4-year-old children", Proceedings of the 35th Annual Meeting of the Cognitive Science Society, Knauff, Markus I Dr. (ur.), Cognitive Science Society, Austin, str. 3169 - 3174 .

- Pavičić Takač, Višnja - Bagarić Medve, Vesna (2013) Jezična $i$ strategijska kompetencija u stranome jeziku, Filozofski fakultet, Osijek.

- Pullum, Geoffrey K. (2012) „A few notes on negative clauses, polarity items, and scope", <http://www.lel.ed.ac.uk/ gpullum/ grammar/negation $>$, (20. X. 2016.). 
- Silić, Josip - Pranjković, Ivo (2007) Gramatika hrvatskoga jezika za gimnazije i visoka učilišta, Školska knjiga, Zagreb.

- Thomson, A. J. - Martinet, A. V. (1995) A Practical English Grammar, Oxford University Press, Oxford.

- Touchie, Hanna Y. (1986) „Second language learning errors: Their types, causes, and treatment", JALT Journal, Japan Association for Language Teaching, god. VIII, br. 1, str. $75-80$.

- Zovko Dinković, Irena (2013) Negacija u jeziku. Kontrastivna analiza negacije u engleskome i hrvatskome jeziku, Hrvatska sveučilišna naklada, Zagreb.

\section{Dodatak A}

Make the sentences negative:

Sue has a black car.

I had seen him.

Karin played volleyball

yesterday.

There will be rain in the South tomorrow.

Mel speaks German.

We are writing a test.

They were having a cup of tea this morning.

She has been to Berlin.

I have been watching TV for an hour.

I am a student.

Listen to Thomas.

It was an unforgettable experience.

They are going to rent a car.

I have got a bag. 
IVA Grubišić ĆURIĆ

Josip Juraj Strossmayer University of Osijek, Faculty of

Agrobiotechnical Sciences

\section{CROATIAN SECONDARY SCHOOL STUDENTS' ERRORS IN FORMING SYNTACTIC NEGATION IN ENGLISH}

\section{Abstract}

The acquisition of negation in the second language has been investigated in numerous studies (Cancino et al., 1975; Meisel, 1997;Fuentes, 2008), however, there are no systematic studies of the acquisition of the English negation by speakers of the Croatian language. The aim of this paper is to gain a better insight into the types and frequency of errors in a relatively free production of negation in English as a second language. The analysis is based on the hypotheses that errors in sentences where the so called dummy do has to be inserted in the negative sentence, omissions of auxiliary verbs, and double marking errors are expected. The analysis is based on a questionnaire consisting of one task of positive to negative sentence transformations. The answers were grouped according to the error type. Errors classified as "other" were the most frequent (37 \%), followed by double marking and congruency errors (14\%), omissions (12\%), and additions (9\%). The results corroborate the frequency hypothesis of errors in sentences where the so called dummy do had to be inserted in the negative sentence, which may be attributed to negative interference from Croatian as the first language.

Keywords: syntactic negation; errors; Croatian; English 